\title{
PENINGKATAN HASIL BELAJAR MATERI BANGUN DATAR PADA SISWA KELAS I SDN 2 KELAYU JORONG MELALUI MEDIA METODE DEMOSTRASI
}

\author{
LILI SURYANI \\ SDN 2 KELAYU JORONG \\ Email: lili339925@gmail.com
}

\begin{abstract}
ABSTRAK
Jenis penelitian yang dilakukan adalah PTK. Tujuan dari penelitian tindakan kelas (PTK) ini adalah untuk mengetahui sejauh mana peningkatkan Hasil belajar siswa pelajaran Matematika Materi Bangun Datar dengan menerapkan Metode Demonstrasi. Dalam penelitian tindakan kelas (PTK) ini dilakukan dalam 2 siklus, dari hasil tindakan yang dilakukan terbukti dapat meningkatkan Hasil belajar siswa dengan mencapai ketuntasan klasikal yang ditetapkan yaitu $85 \%$. Ketuntasan Klasikal $72 \%$ diperoleh pada siklus I, dapat meningkat pada siklus II menjadi $89 \%$. Dari segi aktivitas siswa juga ada peningkatan yaitu pada siklus I diperoleh kategori cukup aktif meningkat menjadi kategori aktif. Hasil penelitian tindakan ini menunjukkan bahwa penerapan Metode Demonstrasi dapat meningkatkan hasil belajar siswa pada pelajaran Matematika Materi Bangun Datar dengan ketuntasan mencapai $89 \%$.
\end{abstract}

Kata Kunci : Hasil belajar, Metode Demonstrasi.

\begin{abstract}
The type of research conducted is PTK. The purpose of this classroom action research (CAR) is to find out the extent to which students' learning outcomes in Mathematics Subjects on Flat Shapes are increased by applying the Demonstration Method. In this classroom action research (CAR), it is carried out in 2 cycles, from the results of the actions taken it is proven to be able to improve student learning outcomes by achieving the classical mastery that is set at $85 \%$. Classical completeness $72 \%$ obtained in the first cycle, can be increased in the second cycle to $89 \%$. In terms of student activity, there was also an increase, namely in the first cycle, the moderately active category increased to an active category. The results of this action research indicate that the implementation of the Demonstration Method can improve student learning outcomes in the Mathematics subject with a flat figure with a completeness of $89 \%$.
\end{abstract}

Keywords: learning outcomes, demonstratio 


\section{PENDAHULUAN}

Pengembangan sumber daya manusia dapat dilakukan, salah satunya melalui pendidikan. Menurut UU RI No. 20 Tahun 2003 tentang Sistem Pendidikan Nasional, pendidikan adalah usaha sadar dan terencana untuk mewujudkan suasana belajar dan proses pembelajaran agar siswa secara aktif mengembangkan potensi dirinya untuk memiliki kekuatan spiritual keagamaan, pengendalian diri, kepribadian, kecerdasan, akhlak mulia, serta keterampilan yang diperlukan dirinya, masyarakat, bangsa, dan negara. Sedangkan menurut Dimyati dan Mudjiono (2006: 7), pendidikan merupakan proses interaksi yang bertujuan. Interaksi terjadi antara guru dan siswa yang bertujuan untuk meningkatkan perkembangan mental sehingga menjadi mandiri dan utuh.

Dirto Hadisusanto (1995: 57) berpendapat bahwa fungsi pendidikan adalah serangkaian tugas atau misi yang diemban dan harus dilaksanakan oleh pendidikan. Di dalam pelaksanaan pendidikan, terdapat tugas-tugas dan misi-misi yang merupakan tanggungjawab pendidikan. Tugas tersebut diantaranya adalah menyelenggarakan pendidikan yang di dalamnya terdapat proses belajar mengajar yang mempunyai misi untuk mencerdaskan siswa.

Sedangkan tujuan pendidikan oleh Dwi Siswoyo (2007: 85) diartikan sebagai sesuatu yang ingin dicapai oleh kegiatan pendidikan. Dalam UU RI No. 20 Tahun 2003 tentang Sistem Pendidikan Nasional, pendidikan nasional bertujuan untuk berkembangnya potensi siswa agar menjadi manusia yang beriman dan bertaqwa kepada Tuhan YME, berakhlak mulia, sehat, berilmu, cakap, kreatif, mandiri, dan menjadi warga negara yang demokratis serta bertanggungjawab. Pendidikan merupakan wadah untuk menciptakan manusia yang cerdas, berbudi luhur, kreatif, mandiri, dan bertanggungjawab terhadap kemajuan bangsa dan negara Indonesia.

Sekolah Dasar merupakan jenjang pendidikan yang memberikan pendidikan dasar sebagai bekal pada jenjang pendidikan selanjutnya. Di Sekolah Dasar, siswa diajarkan konsep-konsep dari materi pelajaran. Guru mempunyai peranan penting dalam hal ini. Menciptakan kegiatan pembelajaran yang menyenangkan bagi siswa merupakan tugas guru. Apalagi mengingat usia anak SD yang berkisar antara 7-12 tahun yang masih suka bermain. Kegiatan pembelajaran yang menyenangkan menjadi motivasi anak untuk giat belajar. Kegiatan pembelajaran yang diciptakan oleh guru juga dapat mempengaruhi anak untuk suka dan tidak suka pada suatu pelajaran. Salah satu pelajaran yang kurang diminati dan diajarkan dengan cara monoton adalah pelajaran matematika.

Matematika yang identik dengan angka-angka dan rumus-rumus dianggap siswa sebagai pelajaran yang harus menguras pikiran mereka dalam memecahkan soal-soal. Padahal, pemahaman siswa terhadap matematika sangat penting karena berkaitan dengan mata pelajaran yang lain. Selain itu, matematika juga dapat berguna dalam kehidupan sehari-hari. Pendekatan yang digunakan dalam mengajarkan matematika harus sesuai dengan materi sehingga dapat mengoptimalkan kegiatan pembelajaran. Guru juga harus mengoptimalkan media yang ada sebagai pendukung dalam mengajarkan materi. Akan tetapi, sebagian besar guru belum menggunakan media pembelajaran yang sesuai dan mendukung pada tiap-tiap materi dalam pelajaran matematika sehingga hasil belajar siswa masih rendah. Padahal, media dalam pembelajaran matematika sangat beragam, seperti kartu bilangan, audio visual, dan sebagainya.

Banyak sekali benda dan alat yang dapat digunakan sebagai media pembelajaran. Media pembelajaran dapat membantu guru dalam menyampaikan materi pelajaran dan menciptakan kegiatan pembelajaran yang menyenangkan. Guru yang dapat mengoptimalkan proses belajar mengajar, maka hasil belajar siswa juga akan optimal. Akan tetapi, melihat kenyataan bahwa masih banyak guru yang menggunakan metode ceramah dan masih teacher centered bukan student centered tanpa menggunakan media apapun akan berpengaruh pada hasil belajar siswa yang rendah. Kegiatan pembelajaran yang kurang disukai siswa akan membuat siswa malas belajar sehingga hasil belajarnya rendah bahkan menurun dari sebelumnya. Hal ini juga terjadi di SDN 2 Kelayu Jorong, khususnya di kelas I. 
Kegiatan pembelajaran pada pelajaran matematika di kelas I SDN 2 Kelayu Jorong masih menggunakan metode ceramah dan teacher centered sehingga ratarata nilai siswa pada pelajaran matematika masih rendah dari standar nilai yang ditentukan sekolah. Nilai yang diperoleh siswa pada pelajaran matematika masih di bawah keriteria ketuntasan minimal (KKM) yaitu 56,4 sedangkan KKM yang di tetapkan yaitu 60. Dari niai rata-rata tersebut presentase ketuntasan 18 siswa ada sebanyak 7 atau $38,8 \%$ yang belum tuntas, sedangkan Hal itu membuktikan bahwa nilai siswa pada mata pelajaran matematika sangat rendah. Hal ini dikarenakan belum mengoptimalkan kegiatan pembelajaran dengan memanfaatkan media pembelajaran sebagai pendukung keberhasilan dalam mencapai tujuan pembelajaran.

Kegiatan pembelajaran merupakan salah satu faktor yang berpengaruh terhadap keberhasilan pemahaman siswa pada materi pelajaran. Pemahaman terhadap materi tersebut akan berpengaruh pada hasil belajar siswa. Kegiatan pembelajaran pada pelajaran matematika sebaiknya menggunakan media pembelajaran. Adanya media pembelajaran akan mempermudah kinerja guru dalam menerangkan materi pelajaran dan membuat siswa lebih mudah paham terhadap materi tersebut. Akan tetapi, dalam menggunakan media pembelajaran harus sesuai dengan materi pelajaran agar media pembelajaran dapat berfungsi dengan baik. Apabila tidak sesuai dengan materi, jangan memaksakan mengaitkan antara materi dan media pembelajaran hanya karena terbatasnya media pembelajaran yang tersedia di sekolah. Media pembelajaran dapat dibuat sendiri oleh guru sesuai dengan materi sehingga akan lebih kreatif dan menyenangkan bagi siswa.

Guru yang profesional dalam mengajar juga akan terbukti dengan dapat menyediakan media pembelajaran yang sesuai dengan materi dan menciptakan suasana belajar yang menyenangkan, serta dapat mengaktifkan siswa sehingga dapat mencapai tujuan pembelajaran yang nantinya akan mengarah pada tujuan pendidikan. Pencapaian tujuan pembelajaran dapat terlihat dari hasil belajar siswa yang berada diatas standar nilai yang ditentukan. Apalagi jika ada peningkatan dalam hasil belajar. Hal itu sangat diharapkan oleh orangtua siswa dan juga pemerintah karena akan tercipta generasi penerus bangsa yang dapat dibanggakan.

Keuntungan dari hasil belajar siswa yang memuaskan juga akan dirasakan oleh sekolah karena para orangtua akan tertarik untuk menyekolahkan anaknya di sekolah tersebut. Keprofesionalan seorang guru dalam menciptakan kegiatan belajar yang memotivasi siswa untuk belajar juga menjadi daya tarik orangtua siswa.

Salah satu media pembelajaran yang dapat digunakan untuk mengajarkan materi bangun datar pada mata pelajaran matematika adalah metode demostrasi. Fungsinya adalah untuk menanamkan konsep bangun datar pada anak, terutama anak SD. Melalui media metode demostrasi, guru dapat mengajarkan macam-macam bentuk bangun datar. Guru juga dapat mengajarkan bagaimana cara mengukur panjang dan lebar, serta cara menghitung luas dan keliling dari bangun datar tersebut.

Bentuk media metode demonstrasi sangat sederhana dan mudah dibuat. Dalam penggunaannya, media metode demostrasi juga mengandung unsur permainan sehingga membuat anak lebih senang belajar. Bahanbahan yang digunakan untuk membuat media metode demostrasi juga mudah diperoleh, ekonomis, dan dapat dipakai berkali-kali. Pembelajaran matematika dengan materi bangun datar menjadi lebih mudah dan menyenangkan dengan media metode demostrasi.

Penanaman konsep menjadi mudah karena siswa berperan aktif dan terlibat secara langsung dalam menggunakan media. Hal tersebut membuktikan bahwa sebuah media yang bagus tidak selalu terbuat dari barang-barang yang dibeli dengan biaya yang mahal. Akan tetapi, hanya butuh kreativitas seorang guru untuk menciptakan media pembelajaran yang mendidik dan menyenangkan. Jadi, dalam membuat suatu media pembelajaran dapat memanfaatkan barang bekas maupun barang-barang di sekitar kita. Oleh karena itu, media pembelajaran menjadi sangat penting dan dibutuhkan guru dalam memperlancar kegiatan pembelajaran. Adanya media pembelajaran akan membuat siswa aktif dan siswa menjadi lebih paham karena terlibat 
langsung dalam proses belajar mengajar. Pemahaman siswa sangat berpengaruh terhadap hasil belajar siswa. Jadi, siswa harus paham terhadap suatu pelajaran agar memperoleh hasil belajar yang memuaskan. Hal ini menjadikan PR (Pekerjaan Rumah) untuk guru dalam merencanakan kegiatan pembelajaran yang dapat memotivasi siswa untuk belajar dan memahami materi.

Berkaitan dengan hal-hal yang dikemukakan di atas, maka peneliti mengambil judul penelitian: "Peningkatan Hasil Belajar Materi Bangun Datar pada Siswa Kelas I SDN 2 Kelau Jorong Melalui Media Metode demostrasi".

\section{KAJIAN PUSTAKA}

\section{Hasil Belajar}

Adanya suatu proses pastinya bertujuan untuk mencapai sebuah hasil. Begitupun dengan proses belajar. Adanya suatu proses dalam belajar akan mencapai suatu hasil belajar. Harapannya adalah sebuah hasil belajar yang optimal. Nana Sudjana (2002: 22) menyatakan bahwa hasil belajar adalah kemampuankemampuan yang dimiliki siswa setelah menerima pengalaman belajarnya. Sedangkan Dimyati dan Mujiono (2009: 3) mengemukakan bahwa hasil belajar merupakan hasil dari suatu interaksi tindak belajar dan tindak mengajar. Jadi, hasil belajar merupakan hasil yang dicapai oleh individu yang berupa kemampuankemampuan tertentu setelah melalui proses belajar dalam jangka waktu tertentu.

Bloom (Suharsimi, 1994: 112) mengklasifikasikan hasil belajar menjadi 3 ranah yang dikenal dengan taksonomi Bloom, yaitu ranah kognitif, ranah afektif, dan ranah psikomotorik. Ketiga ranah tersebut menjadi objek penilaian hasil belajar, di mana masing-masing ranah terdiri dari sejumlah aspek yang saling berkaitan. Alat penilaian untuk setiap ranah juga memiliki karakteristik sendirisendiri karena masing-masing ranah berbeda dalam cakupan dan hakekat yang terkandung di dalamnya.

Keberhasilan dalam suatu proses belajar mengajar ditentukan dari kemampuan guru dalam mengelola kegiatan belajar mengajar. Siswa yang pintar belum tentu mendapatkan nilai maksimal. Peranan guru sangat menentukan keberhasilan kegiatan pembelajaran. Jadi, dalam hal ini, hasil belajar menjadi tolok ukur keberhasilan dalam proses belajar mengajar.

a. Faktor internal, yaitu faktor yang berasal dari dalam diri siswa. Yang termasuk kedalam faktor ini adalah: Faktor Jasmani dan Faktor Psikologis yang meliputi intelegensi, perhatian, minat, bakat, motif, kematangan, dan kesiapan.

b. Faktor eksternal, yaitu faktor yang berasal dari luar diri siswa, yang termasuk kedalam faktor eksternal adalah: Faktor keluarga, Faktor Sekolah, Faktor Masyarakat.

\section{Metode Demonstrasi}

Mulyani Sumantri dan Johan Permana (1999:154) mengemukakan pengertian metode demonstrasi sebagai "cara penyajian pelajaran dengan memperagakan dan mempertunjukkan kepada peserta didik suatu proses, situasi, atau benda tertentu yang sedang dipelajari dengan baik dalam bentuk sebenarnya maupun dalam bentuk tiruan yang dipertunjukkan oleh guru atau sumber belajar lain yang memahami atau ahli dalam topik bahasan yang harus didemonstrasikan."

Metode pembelajaran yang diterapkan pada kegiatan pembelajaran harus sesuai dengan materi dan situasi, serta kondisi kelas sehingga dapat berjalan dengan baik. Oleh karena itu, diperlukan pertimbangan-pertimbangan dalam pemilihan metode mengajar.

a. Kelebihan Metode Demonstrasi

1. Perhatian siswa lebih di pusatkan

2. Proses belajar siswa lebih terarah pada materi yang sedang dipelajari.

3. Pengalaman dan kesan sebagai hasil pembelajaran lebih melekat dalam diri siswa.

b. Kekurangan Metode Demonstrasi

1. Dalam pelaksanaannya, metode demonstrasi memerlukan waktu dan persiapan yang matang,sehingga memerlukan waktu yang banyak. 
2. Demonstrasi

dalam pelaksanaannya banyak menyita biaya dan tenaga (jika memakai alat yang mahal).

3. Tidak semua hal dapat di demonstrasikan di dalam kelas.

4. Metode demonstrasi menjadi tidak efektif jika siswa tidak turut aktif dan suasana gaduh.

c. Langkah-Langkah Metode

Demonstrasi

1. Merumuskan tujuan yang akan dicapai.

2. Mempersiapkan peralatan yang dibutuhkan.

3. Memeriksa appakah peralatan berfungsi atau tidak.

4. Menetapkan langkah pelaksanaan agar efisien.

5. Memperhitungkan dan menetapkan alokasi waktu.

6. Mengatur tata ruang yang memungkinkan seluruh siswa dapat memperhatikan pelaksanaan demonstrasi.

7. Menetapkan kegiatan yang dilaksanakan selama pelaksanaan.

METODE PENELITIAN

1. Setting Penelitian

\section{a. Subyek Penelitian.}

Subyek penelitian adalah siswa kelas 1 SD Negeri 2 Kelayu Jorong kecamatan Selong kabupaten Lombok Timur tahun pelajaran 2021/2022 yang berjumlah 18 siswa dan terdiri atas 10 siswa laki-laki dan 8 siswa perempuan dengan usia rata-rata 7 tahun, karena masa covid-19 sehingga subyek penelitian diambil 18 siswa.

\section{b. Tempat Penelitian $\backslash$}

Penelitian ini dilaksanakan di kelas 1 SD Negeri 2 Kelayu Jorong kecamatan Selong kabupaten Lombok Timur yang merupakan tempat tugas peneliti.

\section{c. Waktu Penelitian.}

Penelitian ini dilaksanakan dengan menggunakan dua siklus, dengan setiap siklusnya dilaksanakan 2 kali pertemuan. Penelitian ini dilaksanakan selama kurang lebih tiga bulan, yaitu mulai Bulan Agustus sampai dengan Oktober 2021.

\section{Prosedur Penelitian}

Dalam penelitian ini peneliti menggunakan desain dengan model Suharsimi Arikunto, 2008: 16

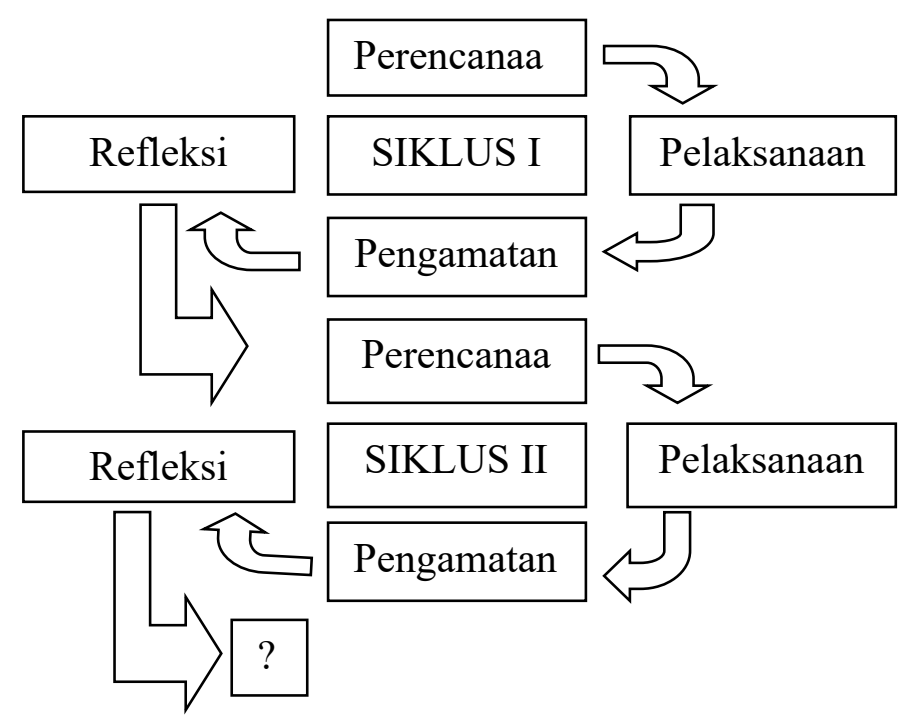

Penelitian ini dilaksanakan dengan menggunakan dua siklus, dengan setiap siklusnya dilaksanakan 2 kali pertemuan yang meliputi :

a. Perencanaan Tindakan 
b. Pelaksanaan Tindakan

c. Observasi dan Evaluasi

d. Refleksi

\section{Tehnik Pengumpulan Data}

a. Instrument Penelitian

1. Instrument pelaksanaan pembelajaran

2. Instrument pengumpulan data

a) Dokumentasi

b) Observasi

c) Tes evaluasi pada setiap siklus

b. Sumber Data

1. Jenis data

2. Cara pengambilan data

c. Indikator Keberhasilan

1. Keberhasilan penelitian ini dilihat dari prestasi belajar mencapai ketuntasan klasikal yaitu jika $\geq$ $85 \%$ siswa mendapat nilai $\geq$ KKM yaitu 60 pada saat evaluasi.

2. Keberhasilan penelitian ini dilihat dari aktivitas belajar siswa minimal berkategori cukup aktif dalam proses pembelajaran materi bangun datar melalui metode demonstrasi, yakni apabila aktivitas belajar siswa berada pada interval $2,5 \leq \mathrm{AS}<$ 3,5 .

\section{Tehnik Pengumpulan Data}

a. Data aktivitas siswa

b. Data tes hasil belajar

\section{HASIL PENELITIAN DAN PEMBAHASAN}

Pada bab ini akan dikemukakan analisis data yang diperoleh dari hasil observasi dan hasil evaluasi pada setiap siklus yang telah direncanakan. Data yang diperolah berupa data kuantitatif dari hasil evaluasi dan data kualitatif yang dikumpulkan dari hasil observasi. Data kuantitatif yang diperoleh dari hasil evaluasi akan memberikan jawaban mengenai keberhasilan atau tidaknya proses pembelajaran dengan menerapkan Metode Demontrasi yang diukur dengan ketuntasan belajar secara klasikal. Data kualitatif diperoleh dari hasil observasi yang akan memberikan gambaran tentang aktivitas siswa maupun aktivitas guru yang dilakukan oleh observer pada setiap pertemuan pelaksanaan proses pembelajaran. Berikut ini akan disajikan data hasil penelitian pada setiap siklus yang telah direncanakan.

\section{Siklus I}

\section{a. Perencanaan}

Pada tahap ini yang akan dilakukan adalah kegiatan membuat rencana pelaksanaan pembelajaran,

\section{b. Pelaksanaan Tindakan}

Dalam tahap pelaksanaan tindakan dilaksanakan kegiatan pembelajaran sesuai dengan rencana pelaksanaan pembelajaran yang telah dibuat. Untuk dapat menyesuaikan rencana pelaksanaan pembelajaran dalam penyampaian materi, termasuk didalamnya pembelajaran dengan menggunakan Metode Demonstrasi dilaksanakan dalam 3 kali pertemuan, dimana 2 kali pertemuan untuk penyampaian materi dan 1 kali pertemuan untuk evaluasi.

\section{c. Observasi dan Evaluasi \\ 1. Hasil Observasi}

Hasil observasi diperoleh dari hasil pengamatan yang dilakukan oleh observer yang dilakukan oleh rekan guru peneliti dengan mengisi lembar observasi aktivitas guru dan aktivitas siswa untuk merekam jalannya proses pembelajaran. Dari hasil observasi dan pengamatan yang dilakukan, didapatkan bahwa proses pembelajaran belum sesuai dengan yang diharapkan karena masih terdapat kekurangan-kekurangan baik dari pihak guru sendiri maupun dari pihak siswa.

Berdasarkan hasil observasi terhadap aktivitas siswa setelah dianalisa diperoleh data sebagai berikut : 
Tabel 4.1. Hasil Observasi Aktivitas Siswa Pada Siklus I

\begin{tabular}{|c|c|c|c|c|c|c|c|c|c|}
\hline \multirow{2}{*}{ Pertemuan } & \multicolumn{6}{|c|}{ Jumlah skor yang tampak } & \multirow{2}{*}{$\begin{array}{c}\Sigma \text { Skor } \\
\text { aktivitas }\end{array}$} & \multirow{2}{*}{$\begin{array}{l}\text { Rata-rata } \\
\text { Aktivitas }\end{array}$} & \multirow{2}{*}{ Kategori } \\
\hline & 1 & 2 & 3 & 4 & 5 & 6 & & & \\
\hline Pertama & 3,7 & 3,3 & 4,0 & 3,3 & 3,3 & 3,0 & 20,6 & 3,4 & $\begin{array}{l}\text { Cukup } \\
\text { Aktif }\end{array}$ \\
\hline Kedua & 3,7 & 3,3 & 4,3 & 3,7 & 3,7 & 3,0 & 21,17 & 3,6 & Aktif \\
\hline
\end{tabular}

Dari tabel di atas dapat dilihat bahwa aktivitas belajar siswa pada siklus I pertemuan 1 adalah 3,4 dengan kategori Cukup Aktif dan pertemuan 2 adalah 3,6 kategori Aktif. Oleh karena itu maka aktivitas siswa pada siklus berikutnya masih perlu ditingkatkan.

\section{Evaluasi Hasil Belajar}

Data lengkap tentang prestasi atau hasil belajar siswa pada siklus 1 berdasarkan hasil evaluasi pada siklus 1 setelah dianalisis diperoleh data sebagai berikut :

Tabel 4.2 : Hasil Evaluasi Belajar Siswa Pada Siklus I

\begin{tabular}{|c|l|l|l|l|l|}
\hline No. & \multicolumn{1}{|c|}{ Nama Siswa } & L/P & Skor & Nilai & $\begin{array}{c}\text { Tuntas/ Tidak } \\
\text { Tuntas(KKM=60) }\end{array}$ \\
\hline 1. & Achmad Afandi & L & 6 & 60 & Tuntas \\
\hline 2. & Atika Apria Nita & P & 7 & 70 & Tuntas \\
\hline 3. & Abdul Ali Hanapi & L & 5 & 50 & Tidak Tuntas \\
\hline 4. & Azriel Maulana & L & 6 & 60 & Tuntas \\
\hline 5. & Arini Lupita Apriani & P & 7 & 70 & Tuntas \\
\hline 6. & Diana Fitriani & P & 7 & 70 & Tuntas \\
\hline 7. & Evril Lrfia Alrsyi & P & 5 & 50 & Tidak Tuntas \\
\hline 8. & Lara Santi Ramadani & P & 7 & 70 & Tuntas \\
\hline 9. & Niswatun Maulida & P & 7 & 70 & Tuntas \\
\hline 10. & Nadia Hirun Nisa & P & 7 & 70 & Tuntas \\
\hline 11. & Muhammad Zein Al-A'afiy & L & 7 & 70 & Tuntas \\
\hline 12. & M.Andika Saputra & L & 5 & 50 & Tidak Tuntas \\
\hline 13. & M.Satriawan Pratama & L & 6 & 60 & Tuntas \\
\hline 14. & Muh.Rizki Alfian Mulyadi & L & 6 & 60 & Tuntas \\
\hline 15. & M.Fathurrohman & L & 7 & 70 & Tuntas \\
\hline 16. & Mutia Azzila Azmi & P & 7 & 70 & Tuntas \\
\hline 17. & Zulqoid Sa'bani & L & 5 & 50 & Tidak Tuntas \\
\hline 18. & M.Safiin & L & 5 & 50 & Tidak Tuntas \\
\hline & Jumlah & & 112 & 1.120 & \\
\hline & Nilai Rata-rata & & & 62 & \\
\hline & Jumlah Siswa Yang Tuntas & & & 13 & \\
\hline & Persentase Ketuntasan Klasikal & & & $72 \%$ & \\
\hline
\end{tabular}

Dari tabel di atas dapat dilihat bahwa ketuntasan belajar yang dicapai siswa adalah $13 \%$ dengan nilai rata - rata 62. Hasil ini belum mencapai ketuntasan belajar secara klasikal sehingga pembelajaran dilanjutkan ke siklus berikutnya.

\section{d. Refleksi}

Berdasarkan analisis hasil observasi pada siklus I, jumlah siswa yang tuntas masih $13 \%$ berarti masih dibawah standar minimum yakni $85 \%$. Hasil tersebut belum mencapai hasil yang diharapkan, untuk itu peneliti melanjutkan ke siklus berikutnya. Dalam siklus I ini terdapat kekurangankekurangan yang perlu untuk dipehatikan dan diperbaiki pada kegiatan siklus II.

\section{Siklus II}

Proses pembelajaran pada siklus II diawali dengan pemberian umpan 
balik dari hasil evaluasi yang diberikan. Oleh karena itu, sebelum berdiskusi guru menghimbau agar siswa tidak ada yang ngobrol, mengganggu temannya yang lain, dan tidak ada siswa yang diam memperhatikan teman-temannya, demikian juga pembagian tugas dalam setiap kelompok harus lebih jelas sehingga siswa dapat melaksanakan tugasnya masing-masing.

\section{a. Perencanaan}

Pada tahap ini yang akan dilakukan adalah kegiatan membuat rencana pelaksanaan pembelajaran.

\section{b. Pelaksanaan Tindakan}

Dalam tahap pelaksanaan tindakan dilaksanakan kegiatan pembelajaran sesuai dengan rencana pelaksanaan pembelajaran yang telah dibuat. Untuk dapat menyesuaikan rencana pelaksanaan pembelajaran dalam penyampaian materi, termasuk didalamnya pembelajaran dengan menggunakan Metode Demontrsi dilaksanakan dalam 3 kali pertemuan, dimana 2 kali pertemuan untuk penyampaian materi dan 1 kali pertemuan untuk evaluasi.

\section{c. Observasi dan Evaluasi}

\section{Hasil Observasi}

Hasil observasi diperoleh dari hasil pengamatan yang dilakukan oleh observer yang dilakukan oleh rekan guru peneliti dengan mengisi lembar observasi aktivitas guru dan aktivitas siswa untuk merekam jalannya proses pembelajaran. Pada saat pembelajaran siklus II telah dilakukan perbaikan, dari analisis hasil observasi aktivitas siswa pada siklus II didapat bahwa aktivitas siswa tergolong aktif dalam setiap pertemuan. Hal ini dapat dilihat pada tabel skor aktivitas siswa mengalami peningkatan dari pertemuan pertama ke pertemuan ke dua, seperti yang terlihat pada tabel dibawah ini

Tabel 4.3. Hasil Observasi Aktivitas Siswa Pada Siklus II

\begin{tabular}{|c|c|c|c|c|c|c|c|c|c|}
\hline \multirow{2}{*}{ Pertemuan } & \multicolumn{6}{|c|}{ Jumlah skor yang tampak } & \multirow{2}{*}{$\begin{array}{c}\Sigma \text { Skor } \\
\text { aktivitas }\end{array}$} & \multirow{2}{*}{$\begin{array}{l}\text { Rata-rata } \\
\text { Aktivitas }\end{array}$} & \multirow{2}{*}{ Kategori } \\
\hline & 1 & 2 & 3 & 4 & 5 & 6 & & & \\
\hline Pertama & 3,7 & 4,0 & 4,0 & 3,7 & 3,3 & 3,0 & 21,7 & 3,6 & Aktif \\
\hline Kedua & 4 & 3,7 & 4,7 & 3,7 & 3,7 & 3,3 & 23,1 & 4 & Aktif \\
\hline
\end{tabular}

Dari tabel diatas dilihat bahwa aktivitas siswa pada siklus II untuk pertemuan 1 adalah 3,6 dan pertemuan 2 adalah 4 .

\section{Evaluasi Hasil Belajar}

Data lengkap tentang prestasi belajar siswa pada siklus II berdasarkan hasil evaluasi pada siklus II setelah dianalisis diperoleh data sebagai berikut :

Tabel 4.4: Hasil belajar yang diperoleh siswa pada siklus II

\begin{tabular}{|c|l|l|l|l|l|}
\hline No. & \multicolumn{1}{|c|}{ Nama Siswa } & L/P & Skor & Nilai & $\begin{array}{c}\text { Tuntas/ Tidak } \\
\text { Tuntas }\end{array}$ \\
\hline 1. & Achmad Affandi & L & 8 & 80 & Tuntas \\
\hline 2. & Atika Apria Nita & P & 9 & 90 & Tuntas \\
\hline 3. & Abdul Ali Hanapi & L & 5 & 50 & Tidak Tuntas \\
\hline 4. & Azriel Maulana & L & 9 & 90 & Tuntas \\
\hline 5. & Arini Lupita Apriani & P & 9 & 90 & Tuntas \\
\hline 6. & Diana Fitriani & P & 9 & 90 & Tuntas \\
\hline 7. & Evril Lrfia Alrsyi & P & 8 & 80 & Tuntas \\
\hline 8. & Lara Santi Ramadani & P & 9 & 90 & Tuntas \\
\hline 9. & Niswatun Maulida & P & 9 & 90 & Tuntas \\
\hline 10. & Nadia Hirun Nisa & P & 9 & 90 & Tuntas \\
\hline 11. & Muhammad Zein Al-A'afiy & L & 9 & 90 & Tuntas \\
\hline 12. & M.Andika Saputra & L & 5 & 50 & Tidak Tuntas \\
\hline 13. & M.Satriawan Pratama & L & 8 & 80 & Tuntas \\
\hline 14. & Muh.Rizki Alfian Mulyadi & L & 8 & 80 & Tuntas \\
\hline
\end{tabular}


Vol. 10. No. 1. Tahun 2022

\begin{tabular}{|c|l|l|l|l|l|}
\hline 15. & M.Fathurrohman & L & 8 & 80 & Tuntas \\
\hline 16. & Mutia Azzila Azmi & P & 9 & 90 & Tuntas \\
\hline 17. & Zulqoid Sa'bani & L & 8 & 80 & Tuntas \\
\hline 18. & M.Safiin & L & 8 & 80 & Tuntas \\
\hline & Jumlah & & 147 & 1.470 & \\
\hline & Nilai Rata-rata & & & 82 & \\
\hline & Jumlah Siswa Yang Tuntas & & & 16 & \\
\hline & Persentase Ketuntasan Klasikal & & & $89 \%$ & \\
\hline
\end{tabular}

Hasil evaluasi yang diperoleh pada siklus II ini mencapai tingkat $89 \%$ jadi sudah dapat dikatakan tuntas, untuk itu tidak perlu lagi diadakan pembelajaran pada siklus berikutnya dengan ketuntasan belajar yang sudah dicapai, dengan demikian pembelajaran dengan menerapkan Metode Demonstrasi dikatakan dapat meningkatkan hasil / prestasi belajar Matematika Materi Bangun Datar.

\section{d. Refleksi}

Dari hasil observasi aktivitas siswa pada siklus II, kegiatan pembelajaran sudah dapat berjalan dengan baik, dimana hasil observasi aktivitas siswa dengan hasil pertemuan 1 kategori Aktif dan pertemun 2 dengan kategori Aktif Dari hasil analisis terhadap hasil evaluasinya terjadi peningkatan rata-rata kelas maupun persentase ketuntasan secara klasikal sudah mencapai/melebihi $85 \%$ artinya sudah $85 \%$ atau lebih siswa sudah mencapai nilai hasil ulangan sebesar KKM atau melebihi KKM yang ditentukan. Oleh karena itu penelitian ini dihentikan sampai siklus II sesuai dengan perencanaan.

\section{PEMBAHASAN}

Penelitian tindakan kelas ini dilaksanakan sebagai upaya untuk meningkatkan Hasil belajar Matemtika Materi Bangun Datar pada siswa kelas Satu dengan melaksanakan pembelajaran dengan menerapkan / menggunakan Metode Demonstrasi di SDN 2 Kelayu Jorong Tahun Pembelajaran 2020/2021.

Berdasarkan hasil analisis data pada tiap siklus, terlihat bahwa hasil dari siklus I ke siklus II mengalami peningkatan. Pada pelaksanaan pembelajaran dan hasil analisis data siklus I, untuk aktivitas siswa diperoleh kategori Aktif) dan aktivitas siswa pada siklus II diperoleh aktivitas siswa dengan kategori (Aktif).

Terkait dengan hasil ulangan pada siklus I dan II dapat dilihat rinciannya dibawah ini :

Tabel 4.5 : Ringkasan Hasil Evaluasi Pada Siklus I

\begin{tabular}{|l|l|c|}
\hline No & \multicolumn{1}{|c|}{ Uraian } & Hasil \\
\hline 1 & Nilai Terendah & 50 \\
\hline 2 & Nilai Tertinggi & 70 \\
\hline 3 & Rata-rata & 6,2 \\
\hline 4 & Jumlah siswa yang tuntas & 13 \\
\hline 5 & Jumlah siswa yang ikut tes & 18 \\
\hline 6 & Persentase yang tuntas & $72 \%$ \\
\hline
\end{tabular}

Sedangkan pada siklus II hasilnya sebagai berikut :

Tabel 4.6 : Ringkasan Hasil Evaluasi Pada Siklus II

\begin{tabular}{|l|l|c|}
\hline No & \multicolumn{1}{|c|}{ Uraian } & Hasil \\
\hline 1 & Skor Terendah & 5 \\
\hline 2 & Skor Tertinggi & 9 \\
\hline 3 & Rata-rata & 82 \\
\hline 4 & Jumlah siswa yang tuntas & 16 \\
\hline 5 & Jumlah siswa yang ikut tes & 18 \\
\hline 6 & Persentase yang tuntas & $89 \%$ \\
\hline
\end{tabular}

Setelah melihat kedua tabel hasil evaluasi dari siklus I dan II dimana nilai yang mereka peroleh sudah mencapai tingkat ketuntasan belajar. Dan melebihi tingkat ketuntasan belajar secara klasikal yaitu $85 \%$.

Penelitian tindakan kelas ini dilaksanaan sebagai upaya untuk meningkatkan aktivitas dan prestasi atau hasil belajar Matematika pada materi Bangun Datar melalui penerapan Metode Demonstrasi Dimana penelitian ini dilakukan dalam dua siklus. 


\section{PENUTUP}

\section{Kesimpulan}

Berdasarkan hasil penelitian dan pembahasan diatas, dapat di simpulkan bahwa Penerapan Metode Demonststrasi dapat meningkatkan aktivitas dan hasil belajar siswa di SDN 2 Kelayu Kelayu Jorong. Peningkatan tersebut dapat dilihat dari perolehan nilai skor aktivitas siswa, dan nilai rata-rata kelas serta tingkat ketuntasan secara klasikal pada tiap siklus mengalami peningkatan baik pada siklus I maupun siklus II.

Dari hasil penelitian dan pembahasan di atas dapatlah kami simpulkan Penerapan Metode Demonstrasi dapat meningkatkan hasil belajar Matematika Materi Bangun Datar pada siswa kelas I SDN 2 Kelayu Jorong Tahun Pelajaran 2021/2022

\section{DAFTAR PUSTAKA}

Azhar.(1993) Proses belajar mengajar pola CBSA Surabaya: Usaha Nasional.

Blom (Suharsimi,1994) Kinerja Pustaka Ilmu Erlangga.

Bruner.(T.wakiman 2001) Psikologi dari Havard University Amerika.

Dalyono.(2001) Psikologi Pendidikan Jakarta: Rineka Cipta.

Dimyati dan Mujiono. (2009) Jakarta: PT Rineka Cipta.

Lismawati Simanjuntak. (1993) Motivasi Mengajar Matematika Jakarta: Rineka Cipta.

Muchtar A.Karim.(1997) Universitas Indraprasta PGRI Jakarta.

Muhibbin syah. (2003) Psikologi belajar. Jakarta : PT Raja Grafindo.

Nana Sudjana,(2002) Metode Statistika Bandung.

Piaget. (Pitadjeng, 2006) Statistik konsep dasar dan apikasinya Jakarta Kencana.
Sri Rumini ,dkk.(1995) Psikologi Pendidikan :FIP IKIP Jakarta.

Sri Subarinah.(2006). Inovasi Pembelajaran $S D$ Jakarta: Depdiknas.

Syapul Sagala.(2006) Strategi Belajar Mengajar Jakarta: Rineka Cipta. 